\title{
Grain yield stability of early maize genotypes
}

${ }^{1}$ Chitra Bahadur Kunwar*, ${ }^{2}$ Ram Bahadur Katuwal,
${ }^{3}$ Sailendra Thapa and ${ }^{1}$ Jiban Shrestha

${ }^{1}$ National Maize Research Program, Rampur, Chitwan, Nepal

${ }^{2}$ Agricultural Research Station Pakhribas, Dhankuta, Nepal

${ }^{3}$ Hill Crops research Program, Kabre, Dolakha, Nepal

*Corresponding author email: chitra2058@gmail.com

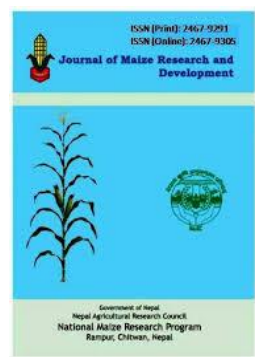

Received: September 2016; Revised: October 2016; Accepted: November 2016

\begin{abstract}
The objective of this study was to estimate grain yield stability of early maize genotypes. Five early maize genotypes namely Pool-17, Arun1EV, Arun-4, Arun-2 and Farmer's variety were evaluated using Randomized Complete Block Design along with three replications at four different locations namely Rampur, Rajahar, Pakhribas and Kabre districts of Nepal during summer seasons of three consecutive years from 2010 to 2012 under farmer's fields. Genotype and genotype $\times$ environment (GGE) biplot was used to identify superior genotype for grain yield and stability pattern. The genotypes Arun-1 EV and Arun-4 were better adapted for Kabre and Pakhribas where as pool-17 for Rajahar environments. The overall findings showed that Arun-1EV was more stable followed by Arun-2 therefore these two varieties can be recommended to farmers for cultivation in both environments.
\end{abstract}

Key words: Early maize genotypes, grain yield, stability

Correct citation: Kunwar, C.B., Katuwal, R.B., Thapa, S., \& Shrestha, J. (2016). Grain yield stability of early maize genotypes. Journal of Maize Research and Development, 2 (1), 94-99, doi: http://dx.doi.org/10.3126/jmrd.v2i1.16219

\section{INTRODUCTION}

Maize (Zea mays L.) is grown under diverse cropping pattern and environments in the hills and Terai. The cropping pattern exists there are maize-wheat, maize-barley, maize-potatoes, maize-fallow and farmers use shorter duration of maize varieties (80-90 days) to catch the winter and spring crops. The productivity of maize in mid and far western region is below the national average. The adoption rate of improved maize varieties is $30 \%$ lower than eastern and western mid-hills (Gurung, 1999). It might be due to longer duration of improved maize varieties which could not fit in the cropping pattern. So, there is need of improved early maize varieties which could fit in the cropping pattern and raise the productivity. The scope of early maize varieties is also in dry ecozones where monsoon is early, higher intensity and longer duration for the intensive cropping system.

The genotypes should be evaluated under different environments before recommending them to farmers. The estimates of GE (genotype-by-environment 
interaction) is very important to establish the breeding objectives like the choice of genitors, identification of the ideal test conditions and recommendations for regional adapted varieties (Yan et al., 2000). The information on stability of early genotypes under Terai and mid-hill environments of Nepal is not sufficient. So, these studies were carried out and the objective of this study was to evaluate the stability and adaptability of five early maize genotypes in four locations using the GGE biplot.

\section{MATERIALS AND METHODS}

Four early maize genotypes namely Pool-17, Arun1EV, Arun-4, Arun-2 and Farmer's variety were evaluated at four different locations namely Rajahar, Rampur, Pakhribas and Kabre during summer seasons of three consecutive years from 2010 to 2012 under farmer's fields. The experimental designs were randomized complete block design with three replications. The plot size was six rows of $3 \mathrm{~m}$ length. The spacing for row to row and plant to plant was $0.75 \mathrm{~m}$ and $0.25 \mathrm{~m}$, respectively. The NPK fertilizer was used @ 120:60:40 kg ha ${ }^{-1}$. The half of $\mathrm{N}$ plus full dose of $\mathrm{P}_{2} \mathrm{O}_{5}$ and $\mathrm{K}_{2} \mathrm{O}$ were used as basal dose application. The remaining half of the $\mathrm{N}$ was divided into two splits and used in two times i.e. at knee-high and pre flowering stages. Rest of agronomic practices was done as per recommendation of National Maize Research Program (NMRP), Rampur, Chitwan, Nepal. Grain yield was calculated using formula adopted by Carangal et al. (1971) and Shrestha et al. (2015) by adjusting the grain moisture at $15 \%$ and converted to the grain yield per hectare. Analysis of variance for grain yield was done using statistical analysis through Genstat programme. All the genotypes were evaluated under 5\% level of significance., The GGE bi-plot software was used to analyze genotype and genotype $\times$ environment (GGE) effects on genotypes across environments (Yan \& Kang, 2003 ).

Table 1. Description of maize genotypes used in experiments

\begin{tabular}{|c|c|c|}
\hline SN & Genotype & Parentage \\
\hline 1 & Pool-17 & $\begin{array}{l}\text { Crosses of the early and late flint materials from mexico, } \\
\text { the Caribean, South and Central America and Asia }\end{array}$ \\
\hline 2 & Arun-4 & Formed using local and elite germplasm \\
\hline 3 & Arun-1 EV & $\begin{array}{l}\text { Crosses of the late flint and early materials from mexico, } \\
\text { the Caribean, South and Central America and Asia }\end{array}$ \\
\hline 5 & Arun-2 & UNCAC-242 × Philippines DMR \\
\hline 6 & Farmers Variety & - \\
\hline
\end{tabular}

Table 2. Geographic description of experimental locations

\begin{tabular}{lccc}
\hline Location & Longitude & Latitude & Elevation $(\mathrm{m})$ \\
\hline Rampur (Chitwan) & $84^{\circ} 19^{\prime} \mathrm{E}$ & $27^{\circ} 40^{\prime} \mathrm{N}$ & 228 \\
Rajahar (Nawalparasi) & $84^{\circ} 14^{\prime} \mathrm{E}$ & $27^{\circ} 41^{\prime} \mathrm{N}$ & 192 \\
Pakhribas (Dhankuta) & $87^{\circ} 17^{\prime} \mathrm{E}$ & $27^{\circ} 02^{\prime} \mathrm{N}$ & 1720 \\
Kabre (Dolakha) & $86^{\circ} 9^{\prime} \mathrm{E}$ & $27^{\circ} 38^{\prime} \mathrm{N}$ & 1788 \\
\hline
\end{tabular}




\section{RESULTS AND DISCUSSION}

Analysis of variance derived from four environments for yield (Table 4) indicated the significant effects of genotype, highly significant effects for environments and their interaction on yield. The maize genotypes were significant for grain yield in different terai and mid hill environments. The Pool-17 produced the significantly highest grain yield (3624 kg ha $\left.{ }^{-1}\right)$ in Rajhar and Arun-2 (3461 kg ha $\left.{ }^{-1}\right)$ for Rampur condition excluding Farmer's Variety. The maize genotypes Arun- 4 and Arun-2 produced significantly higher grain yield under hills condition. This findings were similar to research findings obtained by Fan et al. (2007). The diverse genetic backgrounds of parent genotypes cause the differences among locations. Obi (1991) and Akande and Lamidi (2006) reported that various agronomic characteristics are controlled by diverse genetic factors therefore genotypes perform differently in a particular location.

Table 3: Combined Grain yield of 5 early maize genotypes in Rajahar, Rampur, Pakhribas and Kabre three years of 2010, 2011 and 2012.

\begin{tabular}{lccccc}
\hline Genotypes & Rajahar & Rampur & Pakhribas & Kabre & Combined \\
\hline Arun-1 EV & 3062 & 3040 & 4115 & 4987 & 3801 \\
Arun-4 & 3285 & 2890 & 4820 & 6126 & 4280 \\
Pool-17 & 3624 & 2367 & 3390 & 4021 & 3351 \\
Arun-2 & 2676 & 3461 & 4861 & 5185 & 4046 \\
Farmer's variety & 2754 & 4140 & 3989 & 4280 & 3791 \\
\hline Grand mean & 3080 & 3180 & 4235 & 4920 & 3854 \\
CV\% & 11.3 & 15.4 & 5.7 & 5.5 & 12.1 \\
LSD 0.05 & 462.9 & 558.0 & 672.1 & 748.2 & 979.2 \\
F-test G & $*$ & $*$ & $*$ & $* *$ & $*$ \\
E & & & & & $* *$ \\
G $\times$ E & & & & & $* *$ \\
\hline
\end{tabular}

According to Yan and Kang (2003), an ideal genotype gives the highest yield across tested environments and is stable in its performance. An "ideal" view is drawn (Figure 1) that showed Arun-2 was the closest to the ideal genotype, followed by Arun-1 EV. A genotype closer to the "ideal" genotype is more desirable. The genotypes would be more stable when they are close to the performance line. The biplot (Figure 2) represents a polygon indicating that the vertex genotypes were Arun-2, Arun-4, Pool-17 and Farmer's Variety. 
Table 4. ANOVA for grain yield for the five maize genotypes tested across 4 environments in Nepal (2010-2012).

\begin{tabular}{lccccc}
\hline Source of variation & d.f. & s.s. & m.s. & v.r. & F pr. \\
\hline Replication & 1 & 2151 & 2151 & 0.01 & \\
Genotypes & 4 & 3828763 & 957191 & 4.37 & 0.011 \\
Environment & 3 & 23344058 & 7781353 & 35.55 & $<.001$ \\
Genotypes $\times$ Environment & 12 & 9459798 & 788316 & 3.6 & 0.006 \\
Error & 19 & 4158583 & 218873 & & \\
Total & 39 & 40793352 & & & \\
\hline
\end{tabular}

The genotypes positioned on the vertexes have the longest distance from the biplot origin, they are supposed to be the most responsive either best or the poorest at one or every environment (Yan \& Rajcan, 2002). The allocation of potential mega-environments are shown by "which won where" graph (Yan et al., 2000). The lines perpendicular to the polygon separates the mega-environments. The Arun-1EV and Arun-4 were suitable for Pakhribas and Kabre environments where as Pool-17 for Rajahar and Farmer's variety for Rampur environments (Figure 2).

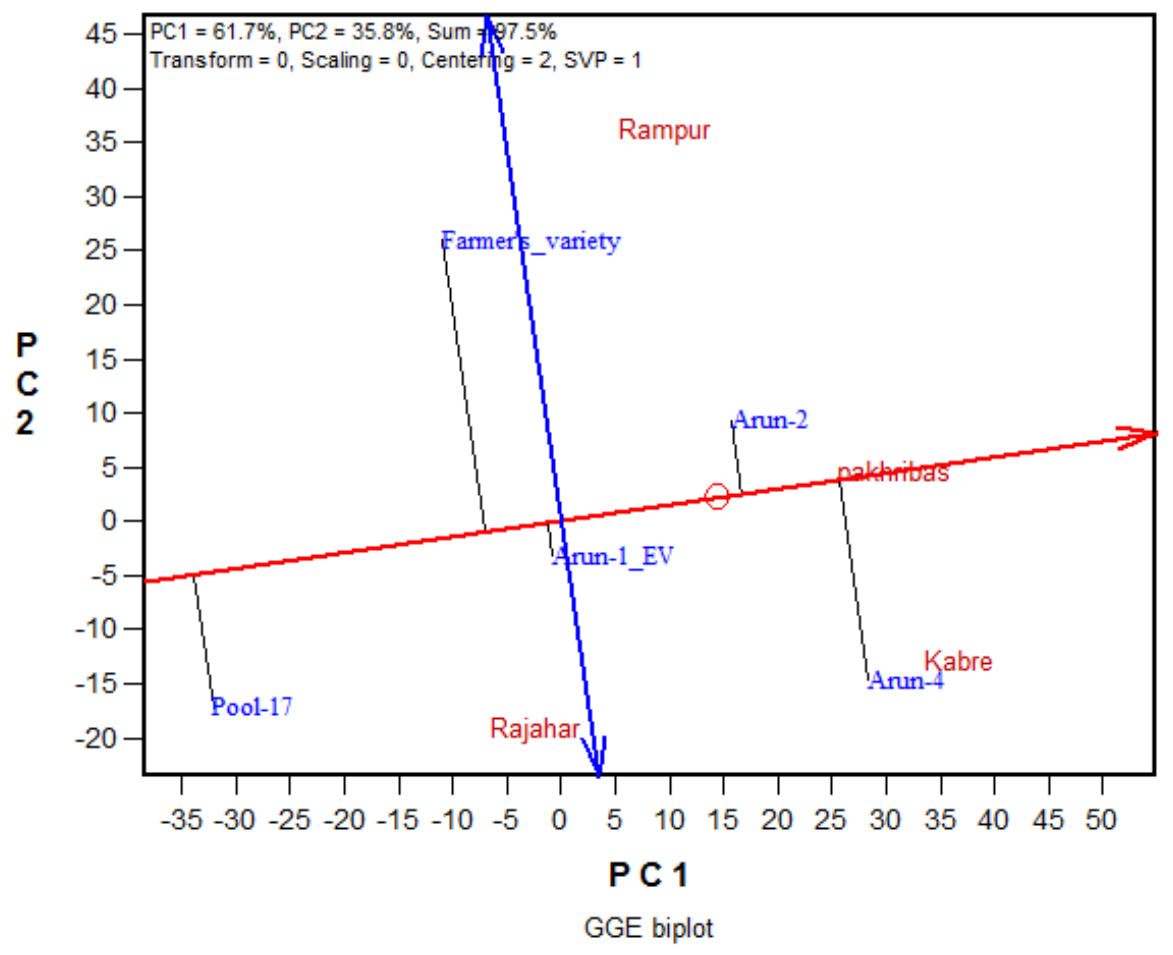

Figure 1. GGE biplot showing ranking of genotypes for mean yield and stability. 


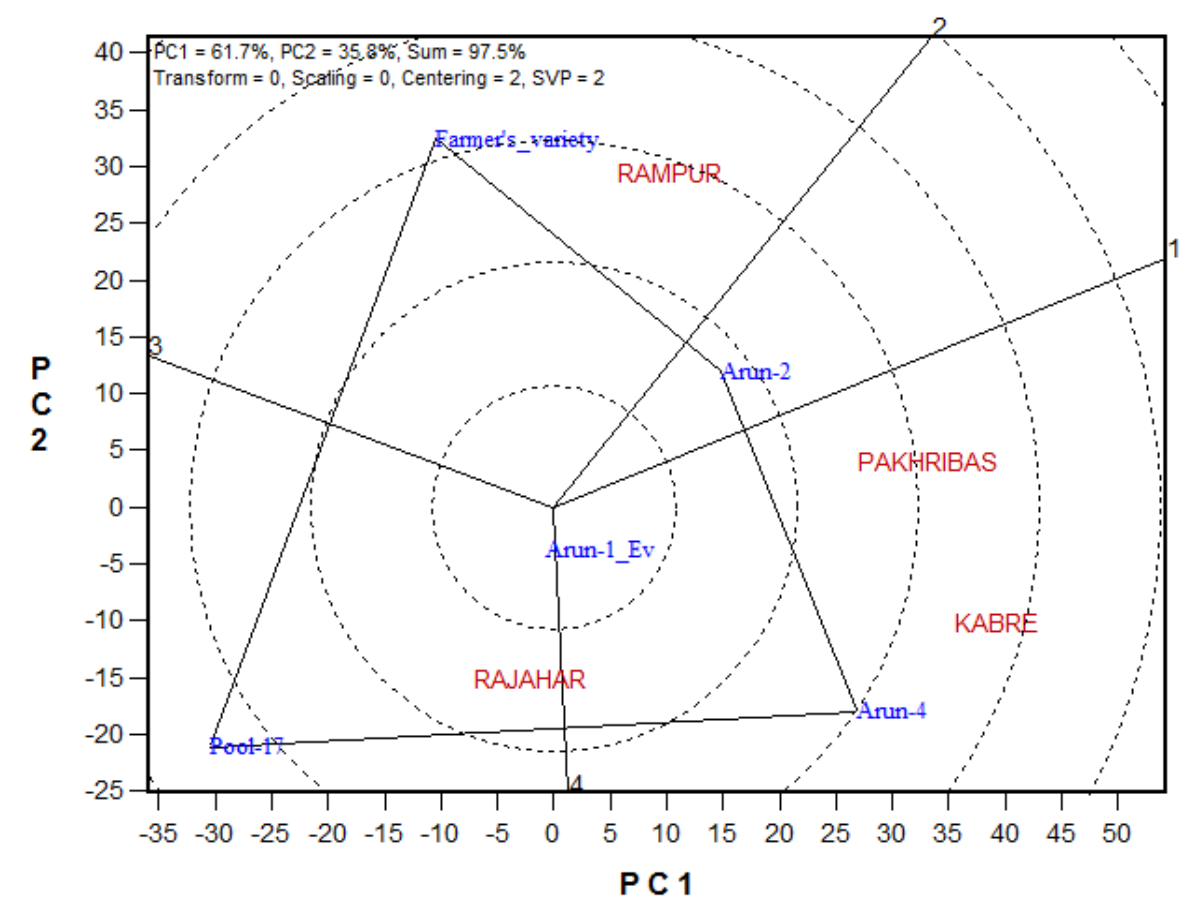

Figure 2. A genotype + genotype $\times$ environment interaction bi-plot showing early maize genotype performance in each environment

\section{CONCLUSION}

Early maize genotypes showed considerable variation in grain yield under the various terai and hill environments in Nepal. The genotypes Arun-1 EV and Arun-4 were more suitable for mid hills and pool-17 for terai. So Arun-1 EV and Arun-2 can be recommended to farmers for general cultivation.

\section{ACKNOWLEDGMENTS}

The authors are grateful to National Maize Research Program for support to carry out the experiments. They would also like to thank to technicians and supporting staffs for help in conducting experiments and data recording.

\section{REFERENCES}

Akande, S.R., \& Lamidi, G.O. (2006). Performance of quality protein maize varieties and disease reaction in the derived savanna agro-ecology of South West Nigeria. Institute of Agricultural Research and Training, Obafemi Awolowo University, Moor Plantation, Ibadan, Nigeria. pp.1-4. 
Carangal, V.R., Ali, S.M., Koble, A.F., \& Rinke, E.H. (1971). Comparison of S1 with testcross evaluation for recurrent selection in maize. Crop Science, 11, 658-661.

Fan, X., Kang, M., Chen, H., Zhang, Y., Tan, J., \& Xu, C. (2007). Yield stability of maize hybrids evaluated in multienvironment trials in Yunnan, China. Agronomy Journal, 99, 220-228

Gurung, D.B. (1999). Potentials and Contraints of the maize based cropping system in the mid and Far Western hills of Nepal. A Survey Report. HARP PP01/98. Report No. 2.

Obi, I.U. (1991). Maize: Its agronomy, diseases, pest and food values. Optimal Computer Solutions Limited. Enugu, publishers. 76 Agbani Road Enugu, Nigeria, XXVIII. Pp. 206.

Shrestha, J., Koirala, K., Katuwal, R., Dhami, N., Pokhrel, B., Ghimire, B., Prasai, H., Paudel, A., Pokhrel, K., \& KC, G. (2015). Performance evaluation of quality protein maize genotypes across various maize production agro ecologies of Nepal. Journal of Maize Research and Development, 1(1), 21-27. doi:http://dx.doi.org/10.3126/jmrd.v1i1.14241

Yan, W., \& Kang, M.S. (2003) 'GGE biplot analysis: a graphical tool for breeders, geneticists, and agronomists.' (CRC Press: Boca Raton, FL)

Yan, W., \& Rajcan, I. (2002). Biplot analysis of test sites and trait relations of soybean in Ontario. Crop Science, 42,11-20.

Yan, W., Hunt, L.A., Sheng, Q., \& Szlavnics, Z. (2000). Cultivar evaluation and megaenvironment investigation based on the GGE biplot. Crop Science, 40,597-605. 